\title{
Natural killer cells in intracranial neoplasms: presence and therapeutic efficacy against brain tumours
}

\author{
Justyna Kmiecik • Jacques Zimmer • \\ Martha Chekenya
}

Received: 2 May 2013/Accepted: 22 September 2013/Published online: 2 October 2013

(C) The Author(s) 2013. This article is published with open access at Springerlink.com

\begin{abstract}
Natural killer (NK) cells are lymphocytes that play an important role in anti-tumour immunity. Their potential against brain cancer has been demonstrated in vitro and in vivo, both as a direct anti-tumour agent and in experimental therapies stimulating endogenous NK cell cytotoxicity. However, the clinical translation of these promising results requires detailed knowledge about the immune status of brain tumour patients, with focus on the NK cell population. In this report, we provide an overview of the studies investigating NK cell infiltration into the tumour, emphasizing the need of revision of the methodologies and further research in this field. We also discuss the potential of using autologous or allogeneic NK cells as effector cells in cellular therapy against brain cancer and developing immunotherapies stimulating endogenous NK cell-mediated anti-tumour response, such as blocking inhibitory killer immunoglobulin-like receptors. Combination of NK cell adoptive transfer with targeted therapies, such as anti-EGFR therapeutic antibody (CetuximAb) could also be a potent strategy.
\end{abstract}

Keywords Tumour infiltrating lymphocytes .

NK cells · Brain tumour · Prognosis · Immunotherapy

$\begin{array}{ll}\text { BBB } & \text { Blood brain barrier } \\ \text { CpG-ODN } & \text { CpG-oligodeoxynucleotides } \\ \text { CTL } & \text { Cytotoxic T lymphocyte } \\ \text { DC } & \text { Dendritic cell } \\ \text { EGFR } & \text { Epidermal growth factor receptor } \\ \text { GBM } & \text { Glioblastoma } \\ \text { GvL } & \text { Graft versus leukemia (effect) } \\ \text { HLA } & \text { Human leukocyte antigen } \\ \text { IFN- } \gamma & \text { Interferon gamma } \\ \text { IHC } & \text { Immunohistochemistry } \\ \text { IL } & \text { Interleukin } \\ \text { KIR } & \text { Killer immunoglobulin-like receptors } \\ \text { LAK cells } & \text { Lymphokine activated killer cells } \\ \text { MHC } & \text { Major histocompatibility complex } \\ \text { MRI } & \text { Magnetic resonance imaging } \\ \text { NCR } & \text { Natural cytotoxicity receptor } \\ \text { NK cells } & \text { Natural killer cells } \\ \text { PBMCs } & \text { Peripheral blood mononuclear cells } \\ \text { rAAV2 } & \text { Recombinant adeno-associated virus 2 } \\ \text { SLMC } & \text { Spontaneous lymphocyte mediated cytotoxicity } \\ \text { TGF } \beta & \text { Transforming growth factor-beta } \\ \text { TLR } & \text { Toll-like receptor }\end{array}$

Introduction: why focus on natural killer cells for brain tumours?

Brain tumours are intracranial neoplasms located in the brain and meninges (excluding haematopoietic malignancies occurring in the brain) and they account for approximately $1.4 \%$ of all cancers $[1,2]$. The incidence of brain and central nervous system tumours worldwide in 2008 was 237,913 new reported cases and is projected to increase to 357,377 by 2030 [3]. Depending on the grade of

J. Kmiecik · M. Chekenya ( $\square)$

Department of Biomedicine, University of Bergen,

Jonas Lies vei 91, 5009 Bergen, Norway

e-mail: martha.chekenya@biomed.uib.no

J. Zimmer

Laboratoire d'Immunogénétique-Allergologie, CRP-Santé,

Luxembourg, Luxembourg 
malignancy, the current standard treatment includes surgery, chemo- and/or radiotherapy. Despite advances in anti-tumour therapy, patients' outcomes remain poor due to inevitable recurrence and malignant progression. One of the challenges in treating brain tumours is the presence of the blood brain barrier (BBB) that limits the access of systemically administered drugs into the tumour site. Due to the BBB, lack of lymphatic drainage and lack of professional antigen presenting cells, brain tumours have been also considered protected from immune system surveillance. However, this concept has been revised, as immune cells have been shown to infiltrate brain tumours [4] and play important roles in both anti-tumour immunity [4] and tumour progression [5, 6].

Natural killer (NK) cells are large granular lymphocytes of the innate immune system. These cells are able to directly lyse infected or transformed cells without specific immunization [7]. NK cells can also recognise the Fc part of antibodies via low affinity Fc $\gamma$ RIIIA (CD16) receptor and perform antibody dependent cellular cytotoxicity (ADCC) of antibody-coated cells [8]. Moreover, they secrete various cytokines and chemokines, such as interferon gamma (IFN- $\gamma$ ) [7]. The recognition of target cells and activation of NK cells is controlled by a balance between activating and inhibitory signals mediated by binding of the ligands expressed on target cells to the receptors expressed on NK cells $[9,10]$. The inhibitory receptors include NKG2A [11] and inhibitory killer immunoglobulin-like receptors (KIRs) $[12,13]$ that recognise major histocompatibility complex (MHC) class I molecules, which are often down regulated on virusinfected or tumour cells. The activating signals are mediated by natural cytotoxicity receptors (NCRs) [14] and NKG2D [14] that recognise ligands expressed on infected or transformed cells, but absent on most normal cells. Some KIR receptors also mediate activating signals, however, they engage the MHC class I ligands with lower affinity than inhibitory KIRs [15]. Upon activation, NK cells induce apoptosis of target cells by secreting granules containing perforin and granzymes [16] or by signalling via death receptors [17].

NK cells play an important role in anti-tumour immunity as several lines of evidence link NK cell surveillance [18], anti-tumour activity [19] and prognostic significance [20$24]$ in various types of cancers. The potential of NK cells as effectors against brain tumours has been demonstrated in vitro $[25,26]$ and in vivo [27, 28, 29]. However, translating these promising results into the clinic requires answers to several important questions related to patients' immune status: (1) Do NK cells infiltrate brain tumours and if yes, are they functional? (2) What is the prognostic significance of NK cells' activity and their infiltration into the tumour? (3) How do the tumour cells escape NK cell-mediated surveillance and killing? Clinical trials using NK cells against brain tumours have already been conducted [30] and some are in progress or recently completed (for example clinicaltrials.gov: NCT00823524 and NCT00909558). Moreover, other experimental therapies might be influenced by patients' NK cell activity [31] and also several treatment strategies have been shown to stimulate NK cell-mediated lysis of tumour cells $[8,27,28$, 32]. Therefore, it is of great importance to take into consideration the brain tumour patients' immune status and encourage further research in this direction. Our review summarizes what is already known in this field and what aspects need further investigation. We also provide an overview of pre-clinical studies conducted and discuss the clinical application of NK cell-based therapy.

\section{What is the immune status of brain tumour patients?}

Numerous studies have investigated the immune system of brain tumour patients, mainly in the context of malignant glioma. Brain tumour patients suffer from extensive immunosuppression due to lymphopenia, decreased lymphocyte proliferation [33, 34] and diminished cytotoxic activity [35], reduced MHC class I expression on monocytes [33, 34] and predominance of anti-inflammatory T-helper 2-type (Th2) cytokine production [33]. In one of the first studies, Servadei et. al analysed cytotoxic functionality of peripheral blood lymphocytes isolated from anaplastic glioma patients and compared with those from bladder and kidney cancer patients and healthy donors [35]. In all three types of cancers they observed decreased ADCC and decreased spontaneous lymphocyte mediated cytotoxicity (SLMC) when comparing to healthy donors, to the greatest extent in anaplastic glioma patients. Reports investigating NK cell numbers and activity in the peripheral blood of glioma patients show conflicting results (reviewed in Dix et al. [33]. The functionality of circulating NK cells is often affected in brain tumour patients and it may result from immunosuppressive factors released by tumour cells. An example is transforming growth factorbeta (TGF $\beta$ ) that down-regulates the expression of NKG2D activating receptor on NK cells isolated from glioblastoma patients compared to those from meningioma patients [36]. Another important factor to be considered is the influence of the standard treatment. Brain tumour patients are immune-compromised due to treatment with steroids [37]. Moreover, decreased absolute numbers of NK cells have been observed in the blood of glioblastoma patients receiving concomitant radiation therapy and temozolomide $^{\mathrm{TM}}[38]$. 
Table 1 NK cell infiltration in intracranial tumours: summary of reviewed literature

\begin{tabular}{|c|c|c|c|c|}
\hline Authors & Tumour type & Method, antibodies & Degree of NK cell infiltration & $\begin{array}{l}\text { Distribution of NK cells } \\
\text { in the tumour tissue }\end{array}$ \\
\hline \multirow[t]{6}{*}{ Stevens et al. [39] } & Gliomas grade IV & IHC, Leu7 and Leu11b & Low & $\begin{array}{l}\text { Within perivascular } \\
\text { cuffs }\end{array}$ \\
\hline & Gliomas grade I-II & & No infiltration & \\
\hline & Carcinoma metastases & & Intermediate & $\begin{array}{l}\text { Around blood vessels } \\
\text { and within tumour } \\
\text { parenchyma }\end{array}$ \\
\hline & Craniopharyngiomas & & Intense & No specific distribution \\
\hline & Meningiomas & & Low & - \\
\hline & Other tumours & & Low & - \\
\hline Vaquero et al. [40] & Brain metastases & IHC, IOT-10 & $\begin{array}{l}\text { Less than } 10 \% \text { of TILs in most } \\
\text { cases }(39 / 40)\end{array}$ & $\begin{array}{l}\text { Mainly associated with } \\
\text { vessels and stroma }\end{array}$ \\
\hline \multirow[t]{2}{*}{ Yang et al. [43] } & Glioblastomas & IHC, CD56 & $\begin{array}{l}\text { Perivascular: intermediate or } \\
\text { extensive in app. } 70 \% \text { cases; } \\
\text { Intratumoural: intermediate in } \\
\text { app. } 25 \% \text { cases, none in app. } \\
50 \% \text { cases }\end{array}$ & $\begin{array}{l}\text { Mostly perivascular/ } \\
\text { extratumoural }\end{array}$ \\
\hline & Pilocytic astrocytoma & & No infiltration & \\
\hline Rossi et al. [46] & Oligodendrogliomas & IHC, Leu11b & No infiltration & \\
\hline Domingues et al. [47] & Meningiomas & $\begin{array}{l}\text { Flow cytometry, NK } \\
\text { cell population } \\
\text { defined as CD3- } \\
\text { CD19-CD56+ }\end{array}$ & $0.2 \pm 0.3 \%$ of all cells & \\
\hline
\end{tabular}

IHC immunohistochemistry, TIL tumour-infiltrating lymphocytes, - no data reported

\section{Do NK cells infiltrate the brain tumour?}

The remaining question was whether the NK cells infiltrate the tumour site. In 1988, Stevens et al. characterised the immune infiltrates in gliomas, carcinoma metastases, craniopharyngiomas and meningiomas [39]. To identify NK cells within the brain tumour tissue, the immunohistochemistry (IHC) technique with Leu7 (CD57) and Leu11b (CD16) antibodies was used (Table 1). They observed that in most glioma cases NK cells were absent, while carcinoma metastases and craniopharyngiomas were more frequently infiltrated by NK cells. Single NK cells were detected in some meningiomas. In all cases, NK cells constituted a minor fraction among all immune cells infiltrating the tumour, leading the authors to conclude that NK cells do not play an important role in anti-tumour immunity in brain cancer. Similar results were obtained by Vaquero et al. for brain metastases [40] with use of the IOT-10 antibody that also recognises CD57. In addition, they showed that the degree of NK cell infiltration varied depending on the origin of metastasis. In a recently published work, the same group reported no correlation of the degree of CD57+ NK cells with the clinical outcome of patients with brain metastasis [41]. The critical point of all those studies is that the CD57 marker is expressed only on a subset of NK cells and is also expressed on a significant fraction of $T$ cells [42]. Therefore a more precise analysis is needed to determine the true frequency and degree of NK cell infiltration in brain tumours.

Contrasting results were reported by Yang et al. [43] in the most recently published work investigating immune cell infiltrates in glioblastomas and comparing it with pilocytic astrocytomas. According to their report, NK cells frequently infiltrated the glioblastomas, whereas this infiltration was negligible in pilocytic astrocytomas. Therefore, contrary to Stevens et al. [39], the authors concluded that NK cells may play an important role in anti-tumour immune responses in glioblastoma patients. In this study the NK cells were identified as CD56+ cells. This method alone might give inaccurate results as CD56 is also expressed by some cytotoxic T cells [44]. According to our observations, NK cells were one of the least numerous immune cell populations of all tumour infiltrating immune cells in glioblastomas $(2.11 \% \pm 0.54, \quad$ mean \pm SEM $)$ and were predominantly $\mathrm{CD} 56{ }^{\mathrm{dim}} \mathrm{CD} 16^{-}$[45]. These results are based on multicolour flow cytometric phenotyping of patients' glioblastoma (GBM) tumour biopsies. The NK cell population was defined as $\mathrm{CD} 3$ negative $\mathrm{CD} 56$ positive.

Concerning oligodendrogliomas, Rossi et al. reported absence of NK cells in those tumours [46]. However, they evaluated the expression of Leu11b (CD16) that is expressed only on the major subpopulation of NK cells. In 
the light of the observations made by Stevens et. al [39], who did not detect Leu11b positive cells despite the presence of Leu7 (CD56) positive infiltrates in various brain tumour specimens and our own studies that did not detect CD16 positive NK cells in GBMs, it is possible that in oligodendrogliomas a similar expression pattern of $\mathrm{CD} 56^{+} \mathrm{CD} 16^{-}$occurs as in the other gliomas.

The most recent study focusing on meningiomas was conducted by Domingues et al. [47] and demonstrated the presence of NK cells within the tumour. Similar to our results and those of Stevens et al., [39], NK cells were one of the least numerous immune cell populations infiltrating the tumour.

\section{Are NK cells a potent anti-tumour agent against brain cancer? Functional studies}

A number of in vitro and in vivo functional studies have been performed in order to investigate the role of NK cells in anti-tumour immunity in brain cancers and the potential of using them as a therapeutic agent. Alizadeh et al. [28] investigated the therapeutic efficacy of a toll-like receptor 9 (TLR9) ligand, CpG-oligodeoxynucleotides (CpG-ODN), in vivo in a murine glioma model. They showed that NK cell numbers in brain, blood and spleen decreased with tumour growth, possibly as a result of tumour-induced immunosuppression. However, they also demonstrated that the therapy they used against glioma induced host immune responses and NK cells mediated the resistance to tumour re-challenge. Another group demonstrated increased cytotoxic activity of splenic NK cells isolated from glioblastoma-bearing animals treated with recombinant adenoassociated virus 2 encoding IL-12 [48]. Dendritic cell (DC) vaccination has also been shown to stimulate IFN $\gamma$ secretion by NK cells and increase their number in the peripheral blood in GBM patients [49]. On the other hand, Alvarez-Breckenridge et al. showed in vivo, that NK cells can negatively influence virotherapy against glioblastoma [31]. Castriconi et al. [25] evaluated the susceptibility of the glioblastoma stem-like cells to NK cell-mediated lysis in vitro. They found that both allogeneic and autologous activated NK cells were able to efficiently kill the GBM cells. However, the GBM cells were resistant to resting NK cells. Avril et al. [26] compared the GBM cells cultured under serum-free conditions with those serum-cultured in a series of cytotoxicity assays using activated NK cells and T cells as effectors. They reported that GBM stem-like cells were more susceptible to both NK cell- and T cell-mediated lysis. Moreover, they showed that in combination with the therapeutic antibody cetuximab, NK cells were able to kill GBM stem-like cells via ADCC. Our team recently demonstrated that combination treatment with NK cells
+ mAb9.2.27 against the NG2/CSPG4 proteoglycan diminished tumor growth that was associated with reduced tumor proliferation, increased cellular apoptosis and prolonged survival compared to vehicle and monotherapy controls. Therapeutic ADCC was mediated by recruitment of CCR2low macrophages into the tumor microenvironment, increased ED1 and MHC class II expression on microglia that rendered them competent for GBM antigen presentation, as well as elevated IFN- $\gamma$ and TNF- $\alpha$ levels in the cerebrospinal fluid compared to controls [29]. The advantages and relevance of these studies were the use of purified NK cells and patient-derived GBM cells.

\section{Can the anti-tumour potential of NK cells be exploited} in the clinic?

The prognostic significance of NK cells' activity has been demonstrated in patients with various solid tumours [20-22, 24]. A higher level of CD57 positive cells infiltration into the tumour correlates with better survival of patients with oesophageal squamous cell carcinoma [20], squamous cell lung cancer [24] and gastric carcinoma [21]. As mentioned before, CD57 is expressed also on a subset of T cells [42], therefore very likely both NK cells and T cells contribute to better patient outcomes. In the study of Kondo et al., a high activity of peripheral NK cells positively correlated with longer survival of colon cancer patients [22]. They also observed that cumulative 5-year metastasis-free rates were higher in the group of patients with high NK cell infiltration (90 vs. $60 \%$ ). These data suggest NK cells play an important role in controlling metastases. Moreover, tumour cells have been shown to express ligands for activating receptors expressed on NK cells $[50,51]$, making them potentially susceptible to NK cell-mediated lysis. Various immunotherapies against brain cancer have been tested so far (reviewed in [52]), including DC vaccination, adoptive $T$ cell transfer, and transfer of lymphokine activated killer (LAK) cells. Most of the clinical trials referring to NK cell activity utilized autologous LAK cells combined with IL-2 injections (recently reviewed in [53]. LAK cells are obtained from peripheral blood mononuclear cells (PBMCs) cultured at conditions that stimulate their expansion and activation. The final product is a mixture of $\mathrm{T}$ cells (majority of them are cytotoxic T lymphocytes (CTLs) and NK cells. Those trials demonstrated partial efficacy and moderate adverse effects (mostly edema) [54, 55]. The weak point of those studies is that the effector cell populations contributing to anti-glioma effect have not been characterised and the mechanisms of treatments tested have not been investigated. However, they showed the potential of cellular therapy against the most malignant brain tumour. 
Therefore, using pure NK cells against solid tumours becomes an attractive alternative strategy to using LAK cells. To date, only one phase I clinical trial has been conducted, where pure autologous NK cells were used as effector cells against brain tumours [30]. In this study, 9 patients with recurrent malignant glioma received intracranial or intravenous injection of NK cells expanded from patients' PBMCs. In 4 of 9 patients, the tumour regression was recorded as magnetic resonance imaging (MRI) radiological response. The benefit in terms of survival outcomes was not evaluated. The authors concluded their therapy was less toxic but was as efficient as LAK cells combined with IL-2. The lower toxicity might be due to the considerably lower doses of IL-2 used. The limited efficacy of experimental therapies utilizing autologous LAK or NK cells might be due to the local and highly integrated tumourinduced immune suppression and immune escape mechanisms. CTLs require antigen presentation and co-stimulation signals that are often impaired in brain tumour patients [45]. Our group has also demonstrated that GBM cells highly express MHC class I molecules [45], that are ligands for inhibitory receptors expressed on NK cells [12]. Therefore, engaging NK cells to kill the tumour cells might require additional, combination treatments that will enhance their activity and/or overcome tumour immune escape mechanisms. One possibility is the use of tumour specific antibodies that would induce ADCC mediated by engaging the Fc $\gamma$ RIIIA receptor (CD16) on NK cells (Fig. 1a). An interesting approach investigated in other solid tumours is the use of fusion proteins comprised of a part recognising the tumour-specific antigen conjugated to a ligand for activating $\mathrm{NK}$ cell receptors, like NKG2D (Fig. 1b) [56]. However, these two strategies are of limited use in the highly heterogeneous brain tumours. There rarely exist in these malignancies tumour-specific antigens that are expressed on all the tumour cells in each patient and that are also absent on the normal cells. Moreover, it may be envisaged that these tumours would eventually escape the treatment by developing antigen loss variants. Reducing NK cell inhibition mediated by interactions of inhibitory KIR receptors with human leukocyte antigen (HLA) ligands may be achieved by blocking KIR receptors with specific antibodies (Fig. 1c). This strategy has been tested in multiple myeloma patients and proved to be safe [57]. Another alternative solution would be the use of allogeneic NK cells instead of patients' own cells (Fig. 1d). The allogeneic NK cells have been shown to mediate the graft versus leukemia $(\mathrm{GvL})$ effect in haematological malignancies [58]. The hypothesized mechanism is the receptor-ligand mismatch between the KIR receptors expressed on donor's NK cells and cognate HLA ligands expressed by recipient's cells resulting in the absence of inhibitory signals mediated by KIR receptors expressed by a subpopulation of NK cells
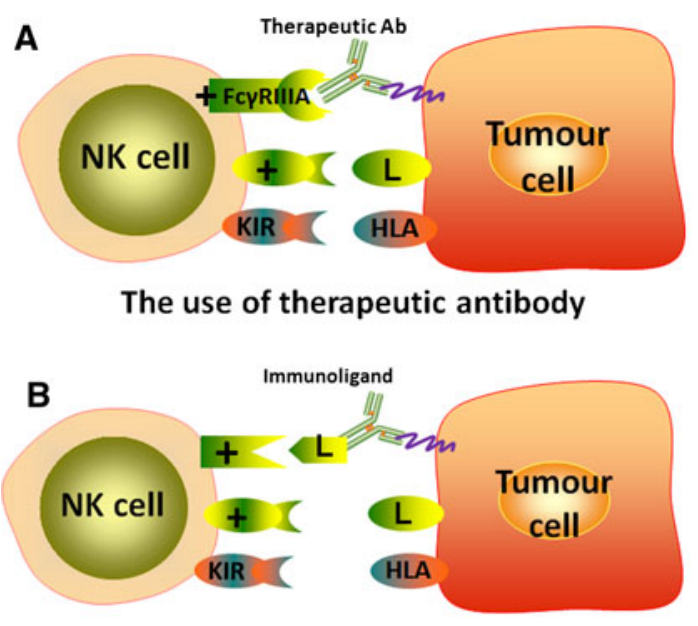

The use of immunoligand
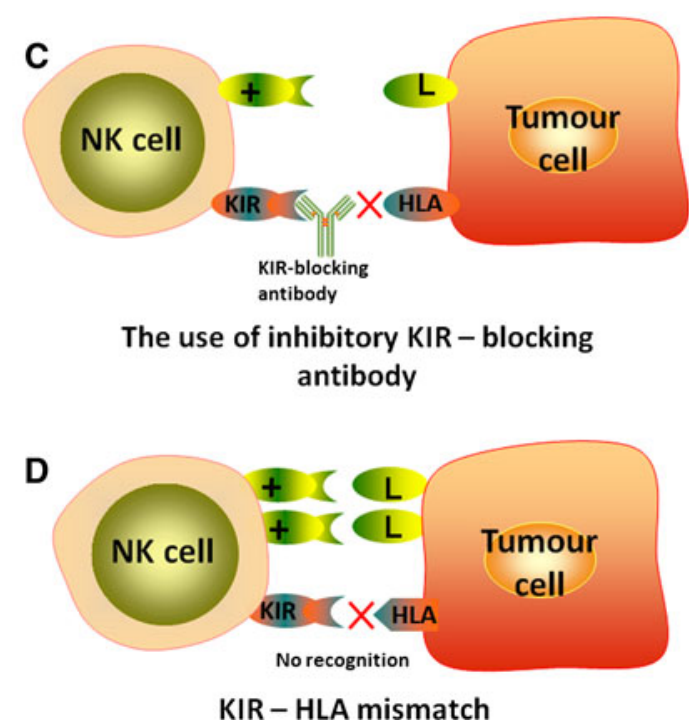

Fig. 1 Treatment strategies for using NK cells against brain tumours. a Therapeutic antibodies, such as cetuximab (anti-EGFR antibody) can induce antibody-dependent cellular cytotoxicity (ADCC) mediated by Fc $\gamma$ RIIIA receptor (CD16) expressed on NK cells. b Immunoligand is a fusion protein: the part recognising specific antigen is conjugated to ligand for activating receptor. Immunoligand binds tumour-specific antigen and stimulates NK cells (endogenous and/or transferred, both autologous and allogeneic) via interaction with activating receptor (e.g. NKG2D). c Applying KIR-blocking antibody reduces the inhibition of both endogenous NK cells as well as adoptively transferred autologous NK cells. d Transfer of allogeneic NK cells with KIR-HLA mismatch approach. Lack of recognition of tumour's HLA by inhibitory KIR receptors results in the absence of inhibitory signals and NK cell activation. + activating receptor, $L$ ligand

[59]. Moreover, the patient's normal cells are spared from killing due to the absence of activating ligands that are expressed almost exclusively on transformed cells. We hypothesise that the same strategy could be used in the treatment of solid tumours, including brain cancer. Moreover, a combination of autologous or allogeneic NK cell- 


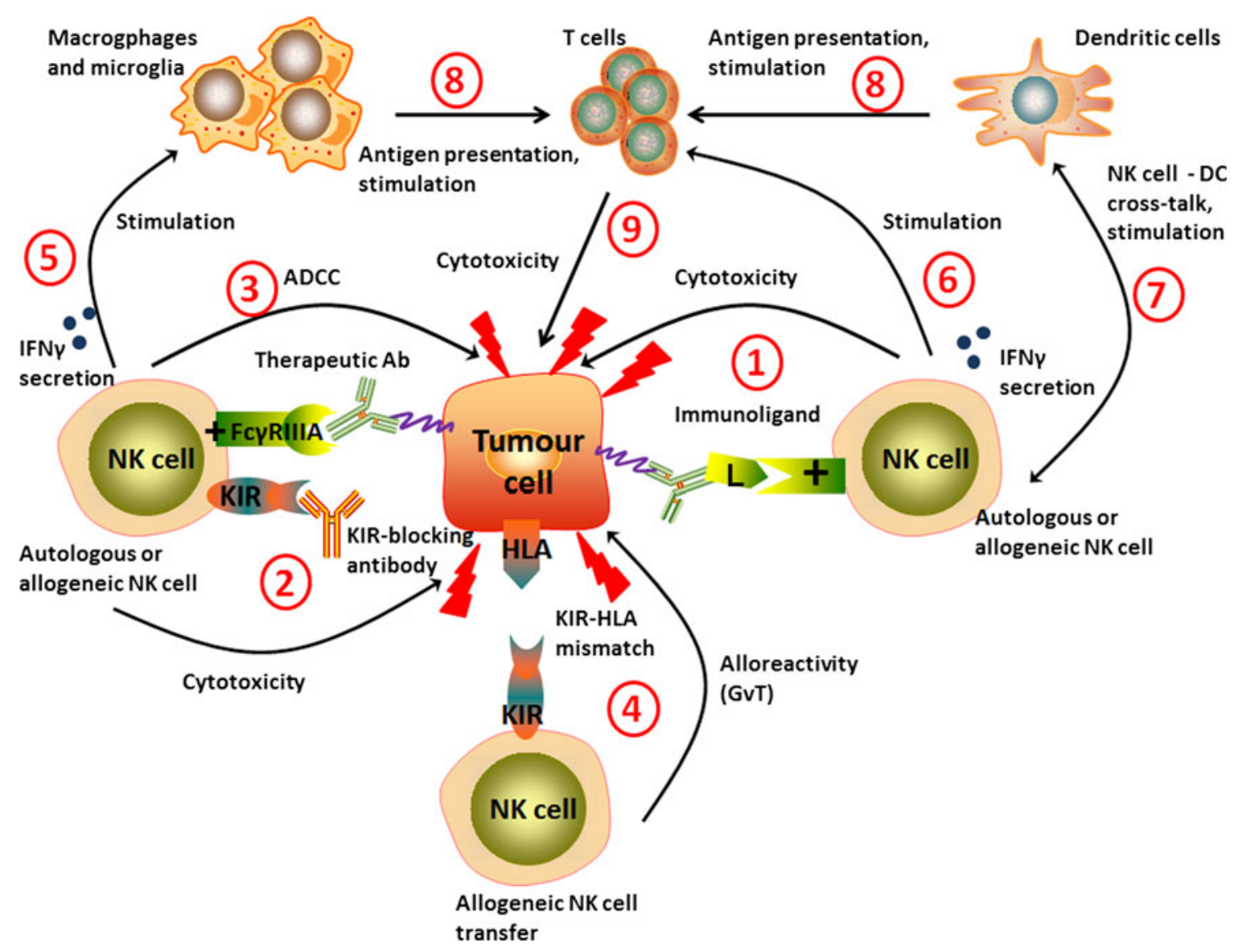

Fig. 2 The interplay of NK and other immune cells in anti-tumour responses. Endogenous and/or adoptively transferred autologous NK cells can be stimulated by immunoligands (1) and/or KIR blocking antibodies (2). Therapeutic antibodies such as cetuximab (anti-EGFR antibody) can induce antibody-dependent cellular cytotoxicity (ADCC) (3). Other possible strategy is cellular therapy with allogeneic NK cells with KIR-HLA mismatch approach (graft vs. tumour effect, GvT) (4). Stimulated and/or alloreactive NK cells are able to directly

based cellular therapy with immune stimulating treatment such as inhibitory KIR-blocking antibody could give better results compared to each of those strategies applied alone. Brain tumour patients could also benefit from combining adoptive transfer of NK cells with already approved therapeutic antibodies such as cetuximab, an anti-epidermal growth factor receptor (EGFR) antibody. Figure 2 summarizes the potential of combination approaches and the role of NK cells in anti-tumour immune response.

\section{Conclusions and perspectives: why do we need further investigation in this field?}

The NK cells have limited access into the nascent brain [60] and they are the least abundant immune cell population within the brain tumour microenvironment. However, different methods used to detect NK cells in the tumour tissue kill the tumour cells, as well as to secrete pro-inflammatory cytokines such as IFN $\gamma$ to further stimulate other immune cells: macrophages, microglia (5) and T cells (6). NK cells may play an important role in DC vaccination due to DC-NK cell cross-talk further stimulating antitumour immune response (7). Stimulated macrophages, microglia and DC can present tumour-associated antigens (8) and induce CTLsmediated cytotoxicity $(9)$. + activating receptor, $L$ : ligand

led to conflicting results. Recent developments give an opportunity to study the infiltration of NK cells with more precise methods, such as with NK cell-specific antibodies or with multicolour flow cytometry with a panel of markers. It is also important to reveal the mechanism of NK cell recruitment, as various experimental therapeutic agents have been demonstrated to stimulate NK cell-mediated antitumour immune responses [8, 27, 28, 32]. NK cells might also influence the efficacy of other anti-cancer treatments [31], therefore their translation into clinic requires knowledge about the patients' immunological status.

Malignant brain tumours develop multiple mechanisms of immune escape and both local, and systemic immunosuppression [33, 36, 45, 61, 62]. Many immunotherapies are based on patients' own immune cells isolated from peripheral blood. Therefore, it is of great importance to investigate the functionality of autologous NK cells in brain tumour patients and the tumour-derived factors that 
could negatively influence NK cell-based therapy. So far, very few studies have been conducted and most of them investigated whole lymphocyte populations [33]. Research focused on pure NK cell fractions could facilitate the development of efficient treatment strategies directly utilizing NK cells as anti-cancer agents or stimulating endogenous NK cells.

To summarize, NK cells play an important role not only in anti-tumour immunity but they are potent effectors that may be considered for developing novel immunotherapies. However, stringent research is required to determine the impact of NK cell infiltration into the tumour site and their therapeutic efficacy in brain tumour patients. Investigating NK cells in the context of brain tumour is also essential for improving the NK cell-based immunotherapies that are increasingly investigated for clinical development for brain tumour patients.

Acknowledgments We thank The Bergen Medical Research Foundation, The Norwegian Cancer Society, The Meltzer Fond, and The Norwegian Research Council FRIFORSK for supporting our research.

Conflict of interest The authors declare no conflict of interests in terms of employment or leadership position, stock ownership, honoraria, research funding, expert testimony or other remuneration.

Open Access This article is distributed under the terms of the Creative Commons Attribution License which permits any use, distribution, and reproduction in any medium, provided the original author(s) and the source are credited.

\section{References}

1. Ali-Osman F (ed) (2005) Brain tumors. Humana Press, New Jersey

2. Dolecek TA, Propp JM, Stroup NE, Kruchko C (2012) CBTRUS statistical report: primary brain and central nervous system tumours diagnosed in the United States in 2005-2009. Neurooncology 14(Suppl 5):v1-v49

3. Ferlay J SH, Bray F, Forman D, Mathers C and Parkin DM: GLOBOCAN 2008 v2.0, Cancer Incidence and Mortality Worldwide: IARC CancerBase No. 10 [Internet]. International Agency for Research on Cancer, Lyon, France

4. Dunn GP, Dunn IF, Curry WT (2007) Focus on TILs: prognostic significance of tumor infiltrating lymphocytes in human glioma. Cancer Immun 7:12

5. Yang I, Han SJ, Kaur G, Crane C, Parsa AT (2010) The role of microglia in central nervous system immunity and glioma immunology. J Clin Neurosci 17:6-10

6. Sonabend AM, Rolle CE, Lesniak MS (2008) The role of regulatory T cells in malignant glioma. Anticancer Res 28:1143-1150

7. Vivier E, Raulet DH, Moretta A, Caligiuri MA, Zitvogel L, Lanier LL, Yokoyama WM, Ugolini S (2011) Innate or adaptive immunity? the example of natural killer cells. Science 331:44-49

8. Seidel UJ, Schlegel P, Lang P (2013) Natural killer cell mediated antibody-dependent cellular cytotoxicity in tumour immunotherapy with therapeutic antibodies. Front Immunol 4:76
9. Lanier LL (2008) Up on the tightrope: natural killer cell activation and inhibition. Nat Immunol 9:495-502

10. Vivier E, Nunes JA, Vely F (2004) Natural killer cell signaling pathways. Science 306:1517-1519

11. Borrego F, Ulbrecht M, Weiss EH, Coligan JE, Brooks AG (1998) Recognition of human histocompatibility leukocyte antigen (HLA)-E complexed with HLA class I signal sequencederived peptides by CD94/NKG2 confers protection from natural killer cell-mediated lysis. J Exp Med 187:813-818

12. Purdy AK, Campbell KS (2009) Natural killer cells and cancer: regulation by the killer cell Ig-like receptors (KIR). Cancer Biol Ther 8:2211-2220

13. Thielens A, Vivier E, Romagne F (2012) NK cell MHC class I specific receptors (KIR): from biology to clinical intervention. Curr Opin Immunol 24:239-245

14. Moretta A, Bottino C, Vitale M, Pende D, Cantoni C, Mingari MC, Biassoni R, Moretta L (2001) Activating receptors and coreceptors involved in human natural killer cell-mediated cytolysis. Annu Rev Immunol 19:197-223

15. Lopez-Botet M, Bellon T, Llano M, Navarro F, Garcia P, de Miguel M (2000) Paired inhibitory and triggering NK cell receptors for HLA class I molecules. Hum Immunol 61:7-17

16. Topham NJ, Hewitt EW (2009) Natural killer cell cytotoxicity: how do they pull the trigger? Immunology 128:7-15

17. Ashkenazi A (2002) Targeting death and decoy receptors of the tumour-necrosis factor superfamily. Nat Rev Cancer 2:420-430

18. Waldhauer I, Steinle A (2008) NK cells and cancer immunosurveillance. Oncogene 27:5932-5943

19. Smyth MJ, Hayakawa Y, Takeda K, Yagita H (2002) New aspects of natural-killer-cell surveillance and therapy of cancer. Nat Rev Cancer 2:850-861

20. Hsia JY, Chen JT, Chen CY, Hsu CP, Miaw J, Huang YS, Yang CY (2005) Prognostic significance of intratumoural natural killer cells in primary resected esophageal squamous cell carcinoma. Chang Gung Med J 28:335-340

21. Ishigami $S$, Natsugoe $S$, Tokuda $K$, Nakajo A, Che $X$, Iwashige H, Aridome K, Hokita S, Aikou T (2000) Prognostic value of intratumoral natural killer cells in gastric carcinoma. Cancer 88:577-583

22. Kondo E, Koda K, Takiguchi N, Oda K, Seike K, Ishizuka M, Miyazaki M (2003) Preoperative natural killer cell activity as a prognostic factor for distant metastasis following surgery for colon cancer. Dig Surg 20:445-451

23. Plonquet A, Haioun C, Jais JP, Debard AL, Salles G, Bene MC, Feugier P, Rabian C, Casasnovas O, Labalette M, Kuhlein E, Farcet JP, Emile JF, Gisselbrecht C, Delfau-Larue MH (2007) Groupe d'etude des lymphomes de la: peripheral blood natural killer cell count is associated with clinical outcome in patients with aaIPI 2-3 diffuse large B-cell lymphoma. Ann Oncol 18:1209-1215

24. Villegas FR, Coca S, Villarrubia VG, Jimenez R, Chillon MJ, Jareno J, Zuil M, Callol L (2002) Prognostic significance of tumour infiltrating natural killer cells subset CD57 in patients with squamous cell lung cancer. Lung Cancer 35:23-28

25. Castriconi R, Daga A, Dondero A, Zona G, Poliani PL, Melotti A, Griffero F, Marubbi D, Spaziante R, Bellora F, Moretta L, Moretta A, Corte G, Bottino C (2009) NK cells recognize and kill human glioblastoma cells with stem cell-like properties. J Immunol 182:3530-3539

26. Avril T, Vauleon E, Hamlat A, Saikali S, Etcheverry A, Delmas C, Diabira S, Mosser J, Quillien V (2012) Human glioblastoma stem-like cells are more sensitive to allogeneic NK and T cellmediated killing compared with serum-cultured glioblastoma cells. Brain Pathol 22:159-174

27. Friese MA, Wischhusen J, Wick W, Weiler M, Eisele G, Steinle A, Weller M (2004) RNA interference targeting transforming 
growth factor-beta enhances NKG2D-mediated antiglioma immune response, inhibits glioma cell migration and invasiveness, and abrogates tumorigenicity in vivo. Cancer Res 64: 7596-7603

28. Alizadeh D, Zhang L, Brown CE, Farrukh O, Jensen MC, Badie B (2010) Induction of anti-glioma natural killer cell response following multiple low-dose intracerebral $\mathrm{CpG}$ therapy. Clin Cancer Res 16:3399-3408

29. Poli A, Wang J, Domingues O, Planagumà J, Yan T, Rygh CB, Skaftnesmo KO, Thorsen F, McCormack E, Hentges F, Pedersen PH, Zimmer J, Enger PØ, Chekenya M (2013) Targeting glioblastoma with NK cells and mAb against NG2/CSPG4 prolongs animal survival. Oncotarget 4(9):1507-1526

30. Ishikawa E, Tsuboi K, Saijo K, Harada H, Takano S, Nose T, Ohno T (2004) Autologous natural killer cell therapy for human recurrent malignant glioma. Anticancer Res 24:1861-1871

31. Alvarez-Breckenridge CA, Yu J, Price R, Wojton J, Pradarelli J, Mao H, Wei M, Wang Y, He S, Hardcastle J, Fernandez SA, Kaur B, Lawler SE, Vivier E, Mandelboim O, Moretta A, Caligiuri MA, Chiocca EA (2012) NK cells impede glioblastoma virotherapy through NKp30 and NKp46 natural cytotoxicity receptors. Nat Med 18:1827-1834

32. Fadul CE, Fisher JL, Hampton TH, Lallana EC, Li Z, Gui J, Szczepiorkowski ZM, Tosteson TD, Rhodes CH, Wishart HA, Lewis LD, Ernstoff MS (2011) Immune response in patients with newly diagnosed glioblastoma multiforme treated with intranodal autologous tumor lysate-dendritic cell vaccination after radiation chemotherapy. J Immunother 34:382-389

33. Dix AR, Brooks WH, Roszman TL, Morford LA (1999) Immune defects observed in patients with primary malignant brain tumours. J Neuroimmunol 100:216-232

34. Parney I (2012) Basic concepts in glioma immunology. In: Yamanaka R (ed) Glioma. Springer, New York, pp 42-52

35. Servadei F, Parente R, Bucci M, Beltrandi E, Tognetti F, Gaist G (1983) Particular features of cell-mediated immunity in patients with anaplastic gliomas. A comparison with kidney and bladder cancer patients. J Neurooncol 1:327-332

36. Crane CA, Han SJ, Barry JJ, Ahn BJ, Lanier LL, Parsa AT (2010) TGF-beta downregulates the activating receptor NKG2D on NK cells and CD8 + T cells in glioma patients. Neuro-oncology 12:7-13

37. Dietrich J, Rao K, Pastorino S, Kesari S (2011) Corticosteroids in brain cancer patients: benefits and pitfalls. Expert Rev Clin Pharmacol 4:233-242

38. Fadul CE, Fisher JL, Gui J, Hampton TH, Cote AL, Ernstoff MS (2011) Immune modulation effects of concomitant temozolomide and radiation therapy on peripheral blood mononuclear cells in patients with glioblastoma multiforme. Neuro-oncology 13: 393-400

39. Stevens A, Kloter I, Roggendorf W (1988) Inflammatory infiltrates and natural killer cell presence in human brain tumors. Cancer 61:738-743

40. Vaquero J, Coca S, Escandon J, Magallon R, Martinez R (1990) Immunohistochemical study of IOT-10 natural killer cells in brain metastases. Acta Neurochir 104:17-20

41. Vaquero J, Zurita M, Coca S (2012) Clinical behavior in metastatic brain disease is not influenced by the immunological defense mediated by CD57 NK-cells. Int J Surg Oncol 2012:834852

42. Lopez-Verges S, Milush JM, Pandey S, York VA, Arakawa-Hoyt J, Pircher H, Norris PJ, Nixon DF, Lanier LL (2010) CD57 defines a functionally distinct population of mature NK cells in the human CD56dimCD16+ NK-cell subset. Blood 116: 3865-3874

43. Yang I, Han SJ, Sughrue ME, Tihan T, Parsa AT (2011) Immune cell infiltrate differences in pilocytic astrocytoma and glioblastoma: evidence of distinct immunological microenvironments that reflect tumor biology. J Neurosurg 115:505-511

44. Pittet MJ, Speiser DE, Valmori D, Cerottini JC, Romero P (2000) Cutting edge: cytolytic effector function in human circulating CD8+ $\mathrm{T}$ cells closely correlates with CD56 surface expression. J Immunol 164:1148-1152

45. Kmiecik J, Poli A, Brons NH, Waha A, Eide GE, Enger PO, Zimmer J, Chekenya M (2013) Elevated CD3+ and CD8+ tumor-infiltrating immune cells correlate with prolonged survival in glioblastoma patients despite integrated immunosuppressive mechanisms in the tumor microenvironment and at the systemic level.J Neuroimmunol. doi:10.1016/j.jneuroim.2013.08.013

46. Rossi ML, Esiri MM, Jones NR, Coakham HB, Moss TH, CruzSanchez FF, Carey MP (1991) Characterization of the mononuclear cell infiltrate and HLA-Dr expression in 19 oligodendrogliomas. Surg Neurol 36:119-125

47. Domingues PH, Teodosio C, Ortiz J, Sousa P, Otero A, Maillo A, Barcena P, Garcia-Macias MC, Lopes MC, de Oliveira C, Orfao A, Tabernero MD (2012) Immunophenotypic identification and characterization of tumor cells and infiltrating cell populations in meningiomas. Am J Pathol 181:1749-1761

48. Chiu TL, Lin SZ, Hsieh WH, Peng CW (2009) AAV2-mediated interleukin-12 in the treatment of malignant brain tumors through activation of NK cells. Int J Oncol 35:1361-1367

49. Pellegatta S, Eoli M, Frigerio S, Antozzi C, Bruzzone MG, Cantini G, Nava S, Anghileri E, Cuppini L, Cuccarini V, Ciusani E, Dossena M, Pollo B, Mantegazza R, Parati EA, Finocchiaro G (2013) The natural killer cell response and tumor debulking are associated with prolonged survival in recurrent glioblastoma patients receiving dendritic cells loaded with autologous tumor lysates. Oncoimmunology 2:e23401

50. Zhang Z, Su T, He L, Wang H, Ji G, Liu X, Zhang Y, Dong G (2012) Identification and functional analysis of ligands for natural killer cell activating receptors in colon carcinoma. Tohoku J Exp Med 226:59-68

51. de Kruijf EM, Sajet A, van Nes JG, Putter H, Smit VT, Eagle RA, Jafferji I, Trowsdale J, Liefers GJ, van de Velde CJ, Kuppen PJ (2012) NKG2D ligand tumor expression and association with clinical outcome in early breast cancer patients: an observational study. BMC Cancer 12:24

52. Vauleon E, Avril T, Collet B, Mosser J, Quillien V (2010) Overview of cellular immunotherapy for patients with glioblastoma. Clin Dev Immunol 2010:2010. doi:10.1155/2010/ 689171. Epub 2010 Oct 4

53. Ishikawa E, Takano S, Ohno T, Tsuboi K (2012) Adoptive cell transfer therapy for malignant gliomas. Adv Exp Med Biol 746:109-120

54. Sankhla SK, Nadkarni JS, Bhagwati SN (1996) Adoptive immunotherapy using lymphokine-activated killer (LAK) cells and interleukin-2 for recurrent malignant primary brain tumors. J Neurooncol 27:133-140

55. Barba D, Saris SC, Holder C, Rosenberg SA, Oldfield EH (1989) Intratumoral LAK cell and interleukin-2 therapy of human gliomas. J Neurosurg 70:175-182

56. Jachimowicz RD, Fracasso G, Yazaki PJ, Power BE, Borchmann P, Engert A, Hansen HP, Reiners KS, Marie M, von Strandmann EP, Rothe A (2011) Induction of in vitro and in vivo NK cell cytotoxicity using high-avidity immunoligands targeting prostatespecific membrane antigen in prostate carcinoma. Mol Cancer Ther 10:1036-1045

57. Benson DM Jr, Hofmeister CC, Padmanabhan S, Suvannasankha A, Jagannath S, Abonour R, Bakan C, Andre P, Efebera Y, Tiollier J, Caligiuri MA, Farag SS (2012) A phase 1 trial of the anti-KIR antibody IPH2101 in patients with relapsed/refractory multiple myeloma. Blood 120:4324-4333 
58. Locatelli F, Pende D, Mingari MC, Bertaina A, Falco M, Moretta A, Moretta L (2013) Cellular and molecular basis of haploidentical hematopoietic stem cell transplantation in the successful treatment of high-risk leukemias: role of alloreactive NK cells. Front Immunol 4:15

59. Bignon JD, Gagne K (2005) KIR matching in hematopoietic stem cell transplantation. Curr Opin Immunol 17:553-559

60. Poli A KJ, Domingues O, Hentges F, Blery M, Chekenya M, Boucraut J, Zimmer J (2013) Natural killer cells in central nervous system disorders. J Immunol 190(11):5355-5362. doi:10. 4049/jimmunol.1203401
61. Zou JP, Morford LA, Chougnet C, Dix AR, Brooks AG, Torres N, Shuman JD, Coligan JE, Brooks WH, Roszman TL, Shearer GM (1999) Human glioma-induced immunosuppression involves soluble factor(s) that alters monocyte cytokine profile and surface markers. J Immunol 162:4882-4892

62. Gomez GG, Kruse CA (2006) Mechanisms of malignant glioma immune resistance and sources of immunosuppression. Gene Ther Mol Biol 10:133-146 